\title{
A Facile Way to Improve the Performance of Perovskite Solar Cells by Toluene and Diethyl Ether Mixed Anti-Solvent Engineering
}

\author{
Haifeng Yang ${ }^{1}\left(\mathbb{D}\right.$, Hui Wang ${ }^{2}$, Jincheng Zhang ${ }^{3}$, Jingjing Chang ${ }^{3}\left(\mathbb{D}\right.$ and Chunfu Zhang ${ }^{3, *(D)}$ \\ 1 College of Physics and Optoelectronics Technology, Medical Micro-Nano Materials Research Center, \\ Baoji University of Arts and Sciences, Baoji 721016, China; faircl@163.com \\ 2 Department of Chemistry and Chemical Engineering, Shaanxi Key Laboratory of Phytochemistry, \\ Baoji University of Arts and Science, Baoji 721013, China; wangkejian@163.com \\ 3 Wide Bandgap Semiconductor Technology Disciplines State Key Laboratory, School of Microelectronics, \\ Xidian University, Xi'an 710071, China; jchzhang@xidian.edu.cn (J.Z.); jjingchang@xidian.edu.cn (J.C.) \\ * Correspondence: cfzhang@xidian.edu.cn
}

Received: 29 October 2019; Accepted: 15 November 2019; Published: 18 November 2019

\begin{abstract}
Solvent engineering is one of the most widely applied preparation methods for the highquality perovskite films. In this method, the choice of anti-solvent plays a very important role to improve the perovskite crystal quality. Here, we report a facile way to regulate the crystal quality of perovskite film by adjusting the ratio of toluene and diethyl ether in the mixed anti-solvent. Through the combination of characterization and measurements including scanning electron microscopy, the atomic force microscopy, X-ray diffraction, and the steady-state photoluminescence spectra, it reveals that the quality of perovskite films is obviously improved when the volume ratio of toluene to diethyl ether in the mixed anti-solvent is 1:1. The optimal device obtains power conversion efficiency of $16.96 \%$ with a short-circuit current density of $20.60 \mathrm{~mA} / \mathrm{cm}^{2}$, an open-circuit voltage of $1.03 \mathrm{~V}$, and a fill factor of $79.96 \%$. At the same time, the device shows negligible current-voltage hysteresis and steady power output. Moreover, the stability of PSCs is significantly enhanced due to the perovskite film quality improvement by adopting $50 \%$ toluene mixed anti-solvent.
\end{abstract}

Keywords: perovskite solar cell; mixed anti-solvent; solvent engineering; film quality; stability enhancement

\section{Introduction}

By virtue of the excellent photoelectric properties of organic-inorganic hybrid perovskite materials, such as high absorption coefficient, ambipolar transport properties, balanced and long charge carrier diffusion length, tunable band gap, etc., the power conversion efficiency (PCE) of perovskite solar cells (PSCs) has surged from $3 \%$ to $25.2 \%$ over the past decade [1-10]. In the photovoltaic community, PSCs can be categorized into two types: Conventional n-i-p structure and inverted p-i-n structure. Generally, PSCs with conventional n-i-p configuration readily achieve higher PCE [9,11,12]. However, electron transporting layers (ETLs) for n-i-p configuration, such as $\mathrm{TiO}_{2}$, require a high fabrication temperature of above $400{ }^{\circ} \mathrm{C}$ and its hole transporting layers (HTLs), typically Spiro-MeOTAD, are synthesized by multiple steps and relatively expensive [11,13]. Especially, there are serious hysteresis effects for the n-i-p configuration [14-16]. Compared to the n-i-p configuration, the p-i-n PSCs, typically consisting of ITO/poly (3,4-ethylenedioxythiophene):poly (styrenesulfonate) (PEDOT:PSS)/Perovskite film/ [6,6]-phenyl-C61-butyric acid methyl ester (PCBM)/Ag, where PEDOT:PSS acts as the HTL and PCBM acts as the ETL, have aroused a lot of attention recently due to less hysteresis effects, relatively low cost, low temperature process, and more compatible fabrication process with flexible substrate for 
wearable applications [17-22]. Although the PCE of p-i-n PSCs was obviously lower than that of n-i-p PSCs at the initial development stage, both types of PSCs have achieved the similar performance at present $[20,23,24]$.

Researchers have been attempting to enhance the PCE and stability of PSCs, which are the two most important obstacles for commercialization of this technology [25-27]. To solve these problems, several strategies have been developed from the following aspects, such as interface engineering [28,29], compositional engineering [12,30,31], new methods of perovskite film growth [32-34], annealing process regulation of the perovskite films [35-37], etc. To achieve smooth, uniform, and pinhole-free perovskite films is the most basic and important step in the preparation of high- performance PSCs. Among various perovskite deposition methods, one step coating method with solvent engineering is widely adopted due to its simple steps and high repeatability. In this method, the key step is anti-solvent which does not dissolve the perovskite film and is easy to get rid of the solvent for perovskite precursor being dripped on the spinning substrate. This step has a decisive influence on the quality of the perovskite film [38].

In the previous reports, a variety of suitable solutions can be used as anti-solvents such as toluene, chlorobenzene, chloroform, diethyl ether, etc. Since these solutions have different physical and chemical properties (Table S1), they have various effects on the film quality of perovskite films. Mohammad Mahdi Tavakoli et al. applied chlorobenzene (CB) as an anti-solvent and significantly improved the crystal quality of perovskite film by introducing formamidinium chloride into the perovskite precursor solution [39]. They further prepared an optimal n-i-p device with PCE up to $21.2 \%$ by surface passivation. Daniel Prochowicz et al. found that adopting isopropanol (IPA) with lower boiling point as an anti-solvent would improve morphology of the perovskite film and enhance the performance of PSC [40]. However, the hysteresis effects of the PSCs treated by IPA were more obvious compared with the PSCs treated by CB. Kun-Mu Lee et al. investigated the effects of toluene, chlorobenzene, isopropyl alcohol, dichlorobenzene, chloroform, etc. as anti-solvents on the morphology, crystal quality of perovskite film, and devices performance [41]. They found that the use of toluene with lower polarity as an anti-solvent is optimal and the optimal volume ratio of toluene to perovskite precursor is about 3:1, which is consistent with the approach adopted by our team $[18,35,42]$. Their best PCE of the p-i-n PSCs is up to $13.12 \%$ with negligible hysteresis effect. Yanbo Gao et al. adopted low boiling point diethyl ether as an anti-solvent to enhance the quality of perovskite films. They found that the quality of the perovskite films is best and the champion n-i-p device achieve PEC of 18.76\% when the volume ratio of diethyl ether to precursor is increased to about 6:1 [43]. Yafei Wang et al. regulated the quality of perovskite films by adding IPA with a relatively low boiling point and low-polar into chlorobenzene as mixed anti-solvent. When $6 \%$ IPA was added into anti-solvent, the best quality of perovskite films with larger grains were achieved [44]. For the method of solvent engineering, the key step is to remove the solvent (DMSO and GBL) in the precursor solution as quickly as possible. Therefore, the anti-solvent with low boiling point such as IPA or diethyl ether was adopted. However, the amount of anti-solvent must be increased during the involvement of an anti-solvent considering the stronger volatility of the anti-solvent with low boiling point as previously report $[40,43]$. On the other hand, the perovskite is very sensitive to the polar solvent. We previously reported that by the method of spin-coating adopting methanol (polarity index $=5.1$ ) as solvent for the interlayer on the perovskite film, the perovskite film will be seriously damaged [42]. As mentioned above, Daniel Prochowicz et al. revealed that adopting IPA (polarity index $=3.9$ ) with higher polarity than chlorobenzene (polarity index $=2.7$ ) as anti-solvent will cause apparent ions accumulation at interfaces between perovskite film and ETL under illumination [40].

In order to take advantage of low boiling and low polar solvents, in this work we chose the mixed solution of toluene, with the lowest polarity index (polarity index $=2.4$, boiling point $=110.6^{\circ} \mathrm{C}$ ), and diethyl ether, with the lowest boiling point (polarity index $=2.8$, boiling point $=34.6{ }^{\circ} \mathrm{C}$ ) in commonly used solvent as the anti-solvent. The quality of the perovskite films is facilely regulated by adjusting the ratio of toluene to diethyl ether in the mixed anti-solvent without increasing the 
amount of anti-solvent. The results show that the perovskite films were more smooth and dense when the volume ratio of toluene to diethyl ether in the mixed anti-solvent is 1:1 through the methods of morphology characterization such as the scanning electron microscopy (SEM) and the atomic force microscopy (AFM). X-ray diffraction (XRD) measurement indicates that the film crystallinity is enhanced and the steady-state photoluminescence (PL) spectra results reveal that the perovskite films have less defects when this mixed anti-solvent is applied. The $J-V$ results under AM 1.5G illumination demonstrate that the PCE of the p-i-n PSCs adopted the toluene/diethyl ether (1:1 volume ratio) mixed anti-solvent can be increased by $12.98 \%$ compared to the control device fabricated with pure toluene as anti-solvent. The optimal device obtains a PCE of $16.96 \%$ with a short-circuit current density (JSC) of $20.60 \mathrm{~mA} / \mathrm{cm}^{2}$, an open-circuit voltage $\left(V_{\mathrm{OC}}\right)$ of $1.03 \mathrm{~V}$, and a fill factor (FF) of $79.96 \%$. Moreover, because the quality of perovskite films is improved by adopting $50 \%$ toluene in the mixed anti-solvent, the stability of the devices can be enhanced as indicated through the stability test. All results indicate that the adoption of the toluene/diethyl ether (1:1 volume ratio) mixed anti-solvent can conveniently and effectively improve the quality of the perovskite film and enhance the performance of the devices.

\section{Materials and Methods}

\subsection{Materials}

All materials and reagents, unless otherwise noted, were of analytically pure quality and used as received. Methylammonium iodide $\left(\mathrm{CH}_{3} \mathrm{NH}_{3} \mathrm{I}, 99.8 \%\right.$, Dyesol, Queanbeyan, NewSouthWales, Australia), $\mathrm{PbI}_{2}$ (99.999\%, Sigma-Aldrich, Saint Louis, MO, USA), Poly(3,4-ethylenedioxythio phene):poly(styrenesulfonate) (PEDOT:PSS, Clevios P VP Al 408, Heraeus, Hanau, Hesse, Germany), Phenyl-C61-butyric acid methyl ester (PCBM, 98\%, American Dye Source, Baie d'Urfé, QC, Canada), Bathocuproine (BCP, 98\%, Alfa Aesar, Ward Hill, MA, USA), Diethyl Ether ( $\geq 99.5 \%$, Rionlon, Tianjin, China), Butyrolactone (GBL, $\geq 99.9 \%$, Aladdin, Shanghai, China). Isopropanol (IPA, anhydrous, 99.5\%), Chlorobenzene (anhydrous, 99.8\%), and Dimethyl Sulfoxide (DMSO, $\geq 99.7 \%$ ), were all acquired from Sigma-Aldrich (Saint Louis, MO, USA).

\subsection{Perovskite Films Formation and Device Fabrication}

ITO substrates $(10 \Omega / \square, 2.0 \mathrm{~cm} \times 2.5 \mathrm{~cm}$ in size) were cleaned by sequential processes: Detergent (solution of 5\% Decon 90 in de-ionized water), de-ionized water, acetone, and alcohol for $15 \mathrm{~min}$, respectively. Additionally, after being dried with nitrogen, they were cleaned in a UV ozone oven for $20 \mathrm{~min}$. After that, a layer of PEDOT:PSS (about $50 \mathrm{~nm}$ ) was coated onto ITO substrates at $7000 \mathrm{rpm}$ for $45 \mathrm{~s}$. After the spin-coating process, they were annealed on the hotplate at $140{ }^{\circ} \mathrm{C}$ for $15 \mathrm{~min}$. For preparation of perovskite films, the substrates were transferred into gloved box in order to eliminate the effects of moisture and oxygen. The $\mathrm{CH}_{3} \mathrm{NH}_{3} \mathrm{PbI}_{3}$ perovskite precursor solution contains $1.4 \mathrm{M}$ $\mathrm{PbI}_{2}$ and $1.35 \mathrm{M} \mathrm{CH}_{3} \mathrm{NH}_{3} \mathrm{I}$ in co-solvent of GBL:DMSO (7:3 volume ratio) and stirred more than $4 \mathrm{~h}$ at $60{ }^{\circ} \mathrm{C}$. The spin-coating process was programmed with two-step coating with $1000 \mathrm{rpm}$ for $15 \mathrm{~s}$ and $5000 \mathrm{rpm}$ for another $25 \mathrm{~s}$, and the volume of the perovskite precursor solution was $110 \mu \mathrm{L}$. The volume ratio of anti-solvent to perovskite precursor solution is about 3:1. During the spin coating process, $350 \mu \mathrm{l}$ different anti-solvent was quickly poured on the samples at the end of $5 \mathrm{~s}$. The anti-solvent was prepared by different toluene: Diethyl ether ratio (the volume ratio was 100:0, 75:25, 50:50, 25:75, and $0: 100$ to obtain $100 \%, 75 \%, 50 \%, 25 \%$, and $0 \%$ toluene in the mixed anti-solvent). All the mixed anti-solvent was shaken to make sure the solvent was homogeneous before being used. The samples were annealed at $100{ }^{\circ} \mathrm{C}$ for $20 \mathrm{~min}$. The perovskite films for the steady PL measurement were prepared as the same process on glasses substrates. The electron transport layer (ETL) was achieved by spin-coating $100 \mu \mathrm{L}$ chlorobenzene solution containing $20 \mathrm{mg} / \mathrm{mL}$ of PCBM at $2000 \mathrm{rpm}$ for $40 \mathrm{~s}$. The thickness of PCBM film was about $50 \mathrm{~nm}$. After that, $100 \mu \mathrm{L} \mathrm{BCP} \mathrm{solution}(0.5 \mathrm{mg} / \mathrm{mL}$ in IPA) was spin-coated on the surface of the ETL (PCBM) at $6000 \mathrm{rpm}$ for $40 \mathrm{~s}$. Finally, $100 \mathrm{~nm}$ thick Ag acting as metal electrode were deposited in metal evaporation chamber under $4 \times 10^{-4} \mathrm{~Pa}$. The active area of the 
cells was $7 \mathrm{~mm}^{2}$ by a shadow mask. The PSCs for stability were tested under ambient air condition with $22{ }^{\circ} \mathrm{C}$ and $\mathrm{RH} \leq 30 \%$ to accelerate the films ageing.

\subsection{Characterization and Measurements}

The surficial morphologies of perovsktie films were characterized on an optical microscope (Nikon Eclipse LV100, Tokyo, Japan) and an extreme-resolution analytical field emission gun-scanning electron microscope (SEM, FEI Quanta 650, Hillsboro, Oregon, USA). The roughness was performed on an atomic force microscopy (AFM, Agilent 5500, Santa Clara, CA, USA). X-ray diffraction (XRD) measurements were recorded on an X-ray diffractometer system (D8 Advance, Bruker, Germany). The UV-vis absorption measurements were carried out by using a UV-vis spectrophotometer (PerkinElmer Lambda 950, MA, USA). J- $V$ curves of PSCs was measured with Keithley 2400 source/meter under an AAA solar simulator (XES-301, SEN-EI Electric. Co. Ltd, Osaka, Japan) with an intensity of $100 \mathrm{~mW} / \mathrm{cm}^{2}$. All the measurements were performed in ambient air atmosphere at room temperature without encapsulation. Incident photo-to-current conversion efficiencies (IPCEs) measurements were performed on SCS10-X150 systems (Zolix Instrument. Co. Ltd, Beijing, China). Photoluminescence spectra were collected on a confocal Raman Microscope, and the excitation wavelength was $633 \mathrm{~nm}$ (HORIBA R-HR 800, Rue du Caducée, France). The data of grain size was collected by software "Nano Measurer".

\section{Results and Discussion}

Figure 1 shows the geometry structure of ITO/PEDOT:PSS/perovskite/PCBM/BCP/Ag and the corresponding schematic band diagram for p-i-n PSCs. Since the BCP interlayer has deeper HOMO energy level $(-7.0 \mathrm{eV})$, it can promote the transport of electrons and at the same time block holes $[45,46]$. Since the perovskite grain boundaries can be passivated due to a slight excess of $\mathrm{PbI}_{2}$ [47], the perovskite precursor containing $1.4 \mathrm{PbI}_{2}$ and $1.35 \mathrm{M} \mathrm{CH}_{3} \mathrm{NH}_{3} \mathrm{I}$ in co-solvent of GBL:DMSO (7:3 volume ratio) is adopted in this paper. Perovskite precursor was spin-coated on a PEDOT:PSS substrate at two-step rotation: (1) Speed $1000 \mathrm{rpm}$ for $15 \mathrm{~s}$, (2) $5000 \mathrm{rpm}$ for another $25 \mathrm{~s}$. During this process, five different anti-solvents were quickly added on the substrates at $35 \mathrm{~s}$ after the beginning of the spin-coating process. We investigated effects of the mixed anti-solvent with five different volume ratios between toluene and diethyl ether $(100 \%, 75 \%, 50 \%, 25 \%$, and $0 \%$ toluene in the mixed anti-solvent) on perovskite films surficial morphology, photoelectric properties, and $J-V$ performance of the cells.

(a)

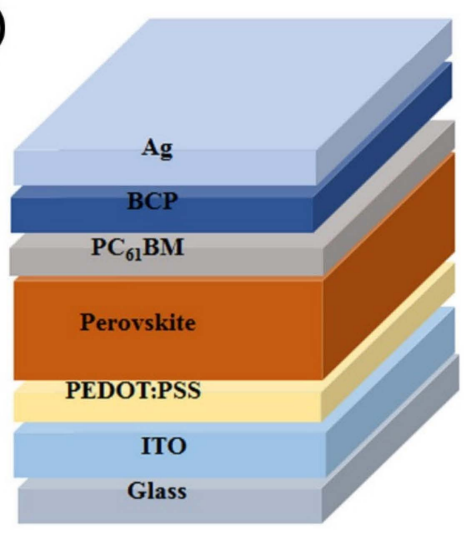

(b)

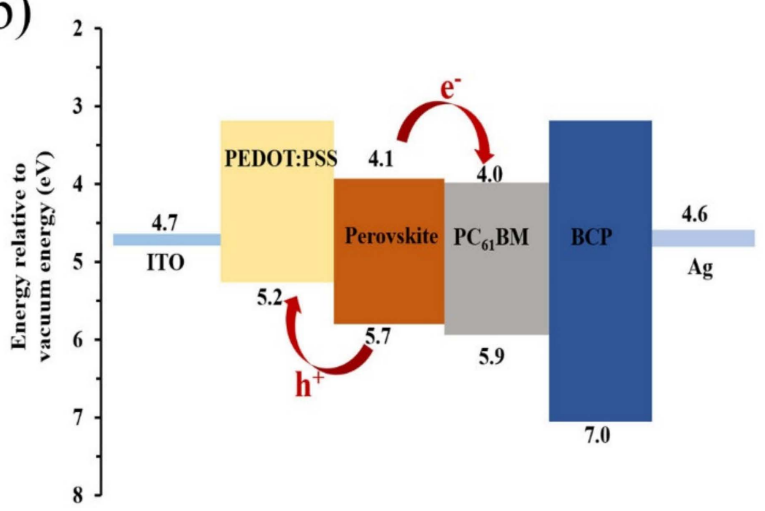

Figure 1. (a) The device geometry structure and (b) the schematic band diagram of p-i-n perovskite solar cell.

During the formation of perovskite films by the solvent engineering method, the involvement of an anti-solvent or not has a very significant effect on the films [38]. This can be seen from 200x magnification optical microscope images (Figure S1a,b) that the film presents a large laminated woven perovskite with a lot of large voids and uncovered areas without involving the anti-solvent. 
However, the control film (adopting pure toluene as anti-solvent) is both dense and uniform. It can be distinguished more clearly from the high-resolution SEM images that the film without involving anti-solvent exhibits large dendritic structure leaving a lot of uncovered areas marked with red circles, while the control film is highly homogenous with outstanding coverage (in Figure S1c,d). At the same time, due to the large difference in surface coverage the absorbance below $600 \mathrm{~nm}$ of the film without involving anti-solvent is significantly lower than that of the control film (Figure S2a). Especially for steady-state photoluminescence (PL) spectra plots as given in Figure S2b, the film without involving anti-solvent has no obvious PL emission peak throughout the entire tested spectra. However, we can observe a small peak at around $760 \mathrm{~nm}$ in the magnify figure. On the contrary, a distinct PL emission peak of the control film is located near $760 \mathrm{~nm}$. Since the quality of the perovskite film without involving anti-solvent is very poor, the devices based on these films are invalid without photovoltaic characteristics.

Intuitively five different ratios of toluene and diethyl ether in the anti-solvent have little effect on the morphology, and all films are relatively uniform and dense, as $200 \times$ magnification optical microscope images was shown in Figure S3. However, the film morphologies are further examined by high-resolution SEM as shown in Figure 2, with the decrease of toluene (or the increase of diethyl ether) volume in the mixed-solvent the grain size of perovskite increases. Statistics of the grain size under different conditions was shown in Figure S4. When the volume ratio of toluene in the mixed anti-solvent is $100 \%, 75 \%, 50 \%, 25 \%$, and $0 \%$, the average grain size is $283.76,309.85,325.60$, 353.60 , and $367.09 \mathrm{~nm}$, respectively. This demonstrates that the grain size of perovskite is inversely proportional to the volume ratio of toluene in the mixed anti-solvent. However, the inhomogeneity of perovskite film is increased as the result of the subsequent AFM characterization when the toluene content is reduced to $25 \%$ and $0 \%$. From the SEM topography images of the different perovskite film, one can see that in some regions (marked blue circle in Figure 2e, $\mathrm{f}$ crystal grains merging occurs to make grains become larger, and small grains appear in the other region. The inhomogeneity of perovskite film is increased when the toluene content is reduced to $25 \%$ and $0 \%$, which can also be inferred from the standard deviation of the statistics of grain size. The standard deviation of grain size for different anti-solvent is $64.33,62.98,45.24,69.54$, and $75.31 \mathrm{~nm}$. When the toluene content is reduced to $25 \%$ and $0 \%$, the standard deviation increases significantly. The red circles in Figure 2e,f refer to the gaps between the enlarged large and small grains. The increase in the gaps can also be explained by the absorption spectrum of the films as shown below.

(a)

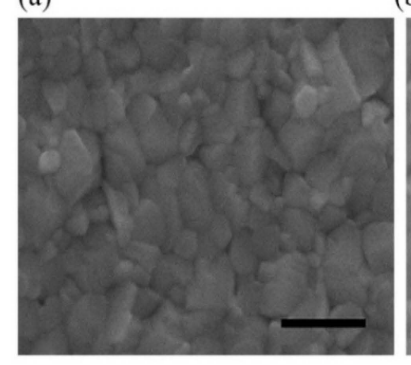

(d)

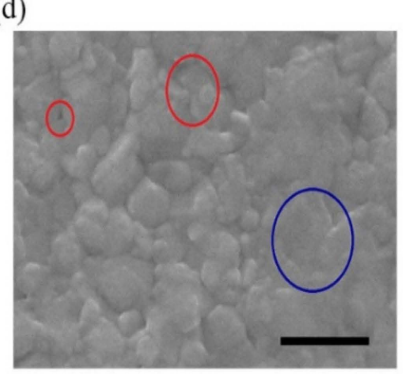

(c)
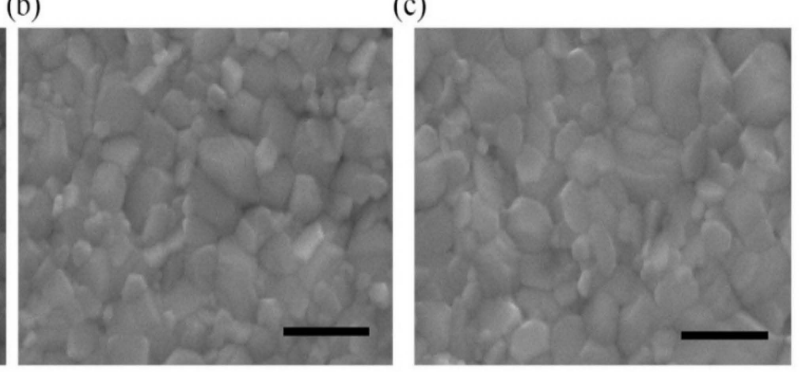

(e)

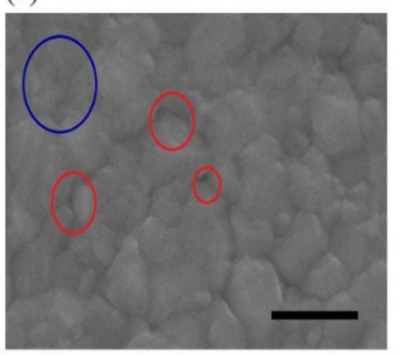

Figure 2. SEM topography images of perovskite films treated with (a) $100 \%$;, (b) $75 \%$, (c) $50 \%$, (d) $25 \%$, and (e) $0 \%$ toluene in the mixed anti-solvent. The scale bar in SEM images is $500 \mathrm{~nm}$. 
It can be obtained that with the increase of low boiling diethyl ether in the mixed anti-solvent the average grain size gradually becomes larger from the properties of the films surface morphology. The reason for this phenomenon is that for the method of solvent engineering, the low boiling point diethyl ether with good volatility can quickly remove the solvent (GBL/DMSO) in the perovskite precursor to promote the growth of perovskite grains. The same results were also found in previous reports [40,43]. However, when the ratio of diethyl ether is increased to $75 \%$ and $100 \%$ without increasing the amount of anti-solvent, the uniformity of the film will be deteriorated. There are two ways to solve this problem: The first one is increasing the ratio of anti-solvent to precursor [43], the second innovation approach is more economical by mixing the high boiling point and low polarity index solvent (toluene) in the anti-solvent as we proposed in this paper.

It also can be demonstrated by the AFM surface images of the perovskite films involving different anti-solvent ratio. As revealed in Figure 3, the root mean square (RMS) roughness of the films is 8.83, 8.66 , and $9.15 \mathrm{~nm}$, respectively when the volume ratio of toluene in the mixed anti-solvent is $100 \%, 75 \%$, and $50 \%$. However, the RMS roughness of the films will increase significantly to 9.81 and $11.05 \mathrm{~nm}$ when the toluene content is reduced to $25 \%$ and $0 \%$.

(a)

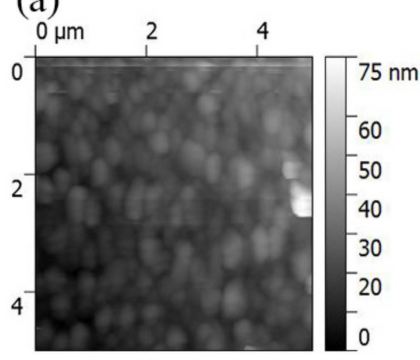

$\mathrm{RMS}=8.83 \mathrm{~nm}$ (b)

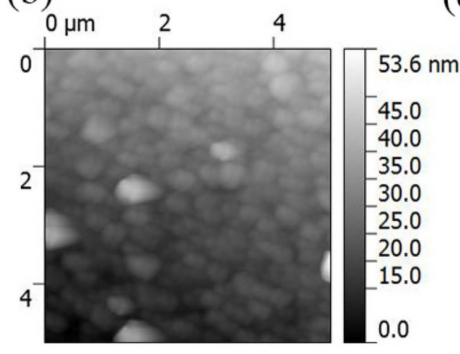

$\mathrm{RMS}=8.66 \mathrm{~nm}$ (c)

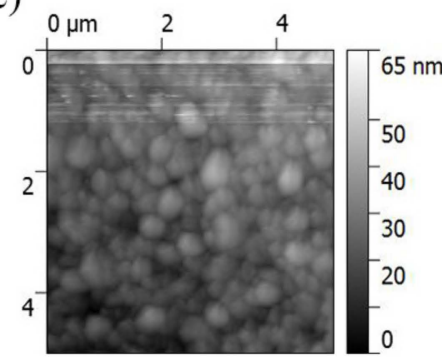

$\mathrm{RMS}=9.15 \mathrm{~nm}$ (d)

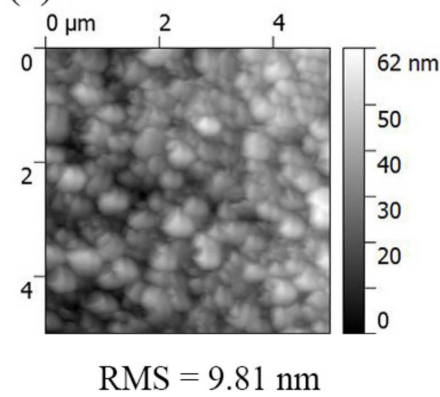

(e)

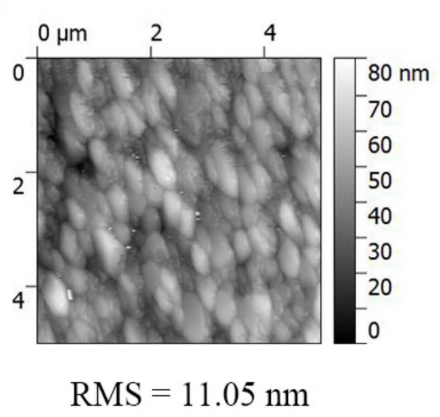

Figure 3. Atomic force microscopy (AFM) images (size: $5 \mu \mathrm{m} \times 5 \mu \mathrm{m}$ ) of perovskite films treated with (a) $100 \%$; (b) $75 \%$; (c) $50 \%$; (d) $25 \%$; and (e) $0 \%$ toluene in the mixed anti-solvent.

Figure 4 demonstrates the evolution of XRD patterns of the perovskite films involving different anti-solvent ratios. The main Bragg diffraction peaks at $2 \theta=14.21,28.51$, and $31.88^{\circ}$ belong to the (110), (220), and (310) crystal faces of tetragonal perovskite crystalline structure, respectively [48,49]. Due to the slight excess of $\mathrm{PbI}_{2}$, the other obvious diffraction peak around $2 \theta=12.6^{\circ}$ corresponded to the (006) planes of $\mathrm{PbI}_{2}$ [50]. It can be seen that when the ratio of toluene in the mixed anti-solvent decrease, the diffraction peak of perovskite is obviously enhanced in the beginning. When the film is treated with equal ratio of toluene and diethyl ether in the mixed anti-solvent, the perovskite diffraction peak intensity is strongest and then gradually decreased. We also calculate the perovskite diffraction peak intensity ratio between (110) and (220) planes as the different anti-solvent was applied. When the proportion of toluene is $100 \%, 75 \%, 50 \%, 25 \%$, and $0 \%$, the ratio is $1.94,2.20,2.31,2.14$, and 1.54, respectively (shown in Table S2). The result demonstrated that the preferred orientation 
of perovskite along (110) plane leading to improved crystallinity of perovskite when the mixed anti-solvent containing $50 \%$ toluene is applied.

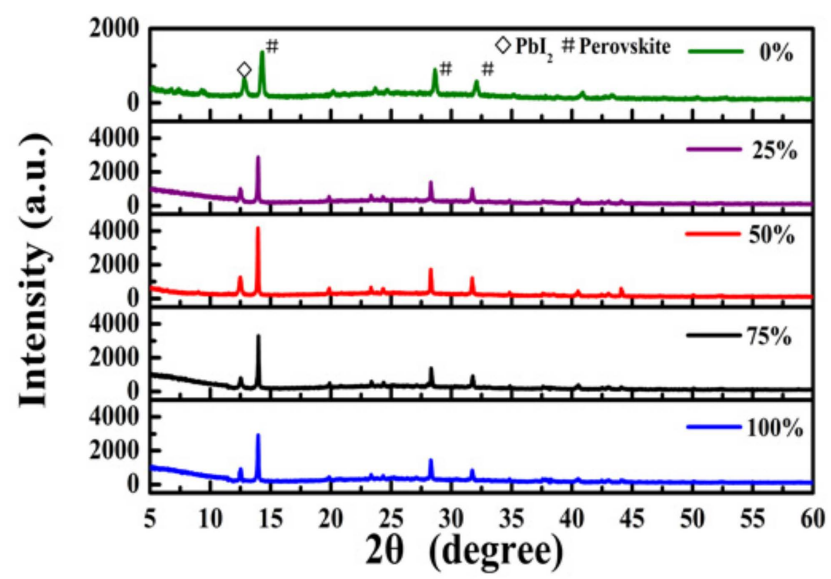

Figure 4. XRD patters of perovskite films treated with $100 \%, 75 \%, 50 \%, 25 \%$, and $0 \%$ toluene in the mixed anti-solvent.

The wavelength-dependent absorbance spectra of the different perovskite films on glass/ITO substrates are observed in Figure 5a. All of the absorption onset seems the same for the five different perovskite films, which are at around $790 \mathrm{~nm}$ corresponding to an optical band gap of $1.57 \mathrm{eV}$ and is similar to our previous reports [35,42]. When the volume ratio of toluene is reduced from $100 \%$ to $50 \%$, the light absorption of the films are slightly improved, which may be the result of the increasement of crystal grain size and crystallinity. However, as the content of toluene continues to decrease to $25 \%$ and $0 \%$, the light absorption are reduced due to the increase of the RMS roughness and the inhomogeneity of the perovskite films surface (inset of Figure 5a). Steady-state PL spectra for five kinds of perovskite films involving different anti-solvent were also measured (Figure $5 \mathrm{~b}$ ), all films were disposed on glass substrates in order to avoid carries quenching at the interfaces. The perovskite film with 50\% volume ratio of toluene in the mixed anti-solvent exhibits a PL emission much stronger than other films. It indicates the perovskite film treated with equal ratio between toluene and diethyl ether achieves fewer defects associated with non-radiative recombination centers [51,52].

(a)

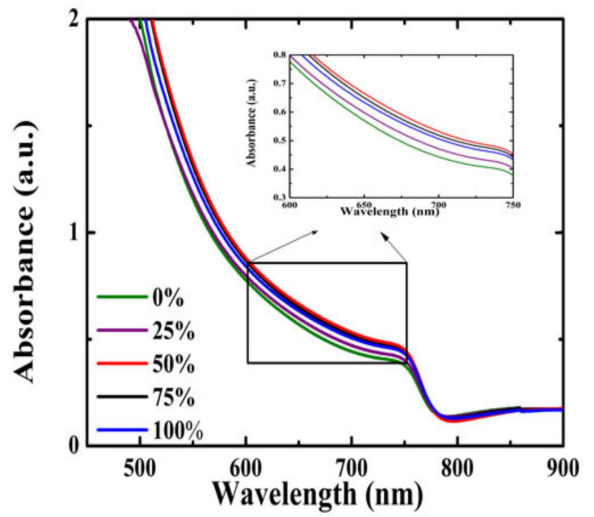

(b)

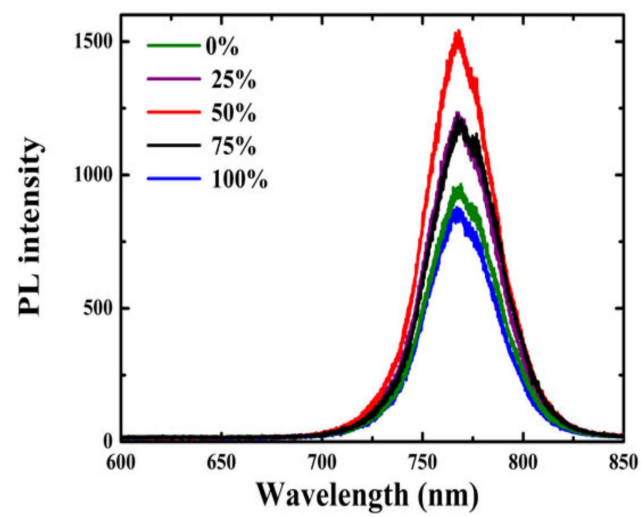

Figure 5. (a) The wavelength-dependent absorbance spectra and (b) steady-state photoluminescence (PL) spectra for perovskite films treated with $100 \%, 75 \%, 50 \%, 25 \%$, and $0 \%$ toluene in the mixed anti-solvent.

Table 1 summarizes the photovoltaic performance parameters of PSCs fabricated with distinct anti-solvent under AM1.5 G illumination. When the proportion of toluene in the mixed anti-solvent is $50 \%, J_{S C}$ is improved to $20.33 \pm 0.69 \mathrm{~mA} / \mathrm{cm}^{2}$ and the corresponding PCE is $16.02 \% \pm 0.72 \%$ which 
is the highest in the five different anti-solvents. As the ratio of toluene in the mixed anti-solvent is reduced to $0 \%$, due to the poor film quality obtained from adopting completely diethyl ether as anti-solvent, $V_{\mathrm{OC}}, J_{\mathrm{SC}}$, and FF have a certain degree of decline, and the corresponding PCE drops to $13.55 \pm 0.53 \mathrm{~mA} / \mathrm{cm}^{2}$. The statistics on the photovoltaic parameters are also given in Figure 6 .

Table 1. Summary of photovoltaic parameters of perovskite solar cells (PSCs) obtained by different mixed anti-solvent under air mass (AM) $1.5 \mathrm{G}$ solar light $\left(100 \mathrm{~mW} / \mathrm{cm}^{2}\right)$.

\begin{tabular}{cccccc}
\hline $\begin{array}{c}\text { Proportion of Toluene } \\
\text { in the Mixed } \\
\text { Anti-Solvent (\%) }\end{array}$ & $V_{\text {OC }}(\mathbf{V})$ & $J_{\text {SC }}\left(\mathbf{m A} / \mathbf{c m}^{2}\right)$ & FF (\%) & PCE (\%) & Best PCE (\%) \\
\hline $100 \%$ & $0.992 \pm 0.015$ & $19.02 \pm 0.36$ & $75.17 \pm 2.65$ & $14.18 \pm 0.36$ & 14.59 \\
$25 \%$ & $1.001 \pm 0.016$ & $19.80 \pm 0.97$ & $77.88 \pm 2.69$ & $15.41 \pm 0.43$ & 15.85 \\
$50 \%$ & $1.013 \pm 0.014$ & $20.33 \pm 0.69$ & $77.81 \pm 2.58$ & $16.02 \pm 0.72$ & 16.96 \\
$75 \%$ & $0.988 \pm 0.020$ & $19.50 \pm 0.91$ & $76.38 \pm 2.59$ & $14.70 \pm 0.48$ & 15.39 \\
$0 \%$ & $0.973 \pm 0.017$ & $18.21 \pm 0.73$ & $73.82 \pm 3.25$ & $13.55 \pm 0.53$ & 13.81 \\
\hline
\end{tabular}

(a)

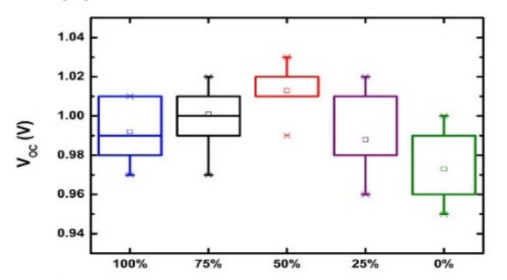

(c)

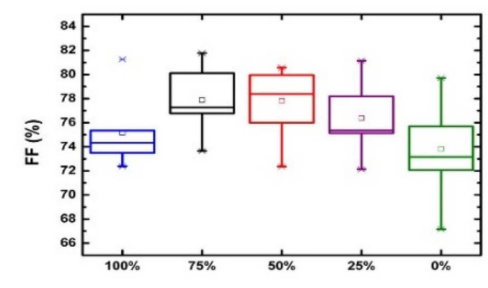

(b)

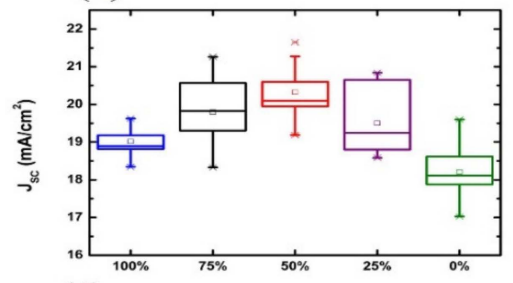

(d)

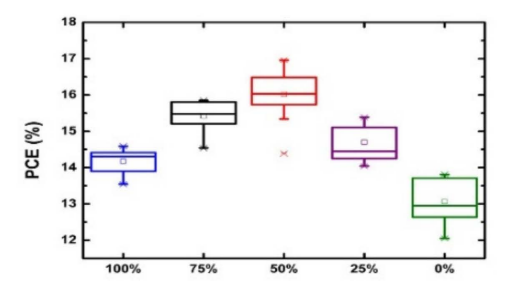

Figure 6. Statistic parameters of (a) open-circuit voltage $\left(V_{\mathrm{OC}}\right)$; (b) short-circuit current density (JSC); (c) fill factor (FF); and (d) power conversion efficiency (PCE) for PSCs prepared by 100\%, 75\%, 50\%, $25 \%$, and $0 \%$ toluene in the mixed anti-solvent.

The optimal device shows a champion PCE of $16.96 \%$ with a $V_{\mathrm{OC}}$ of $1.03 \mathrm{~V}$, a $J_{\mathrm{SC}}$ of $20.60 \mathrm{~mA} / \mathrm{cm}^{2}$, and a FF of 79.95\% under the forward scanning (FS) direction. Additionally, under the reverse scanning (RS) direction, the device shows a PCE of $16.54 \%$ with a $V_{\mathrm{OC}}$ of $1.04 \mathrm{~V}$, a $J_{\mathrm{SC}}$ of $19.78 \mathrm{~mA} / \mathrm{cm}^{2}$, and a FF of $80.45 \%$ (as presented in Figure 7a). Since the hysteresis index [53] of this device is only 0.036, the device exhibits less hysteresis effect. The hysteresis effect of PSCs is related to many factors, especially the quality of perovskite film $[53,54]$. The hysteresis indices (HI) of PSCs with different mixed anti-solvent were extracted as listed in Table S3. It reveals that the device exhibits less hysteresis effect when using 50\% toluene anti-solvent. Figure $7 \mathrm{~b}$ indicates the steady photocurrent and the maximum PCE at the bias voltage of $0.88 \mathrm{~V}$ over $200 \mathrm{~s}$, the results are also in line with that from photovoltaic performances measurements, further demonstrating that cells have trustworthy and steady power output. The wavelength-dependent photo-to-current conversion efficiency of PSCs is provided by insight into the results of IPCE. From the IPCE curve of the champion device range from 300 to $800 \mathrm{~nm}$ (as shown in Figure 7c), the maximum IPCE exceeds 90\% near $540 \mathrm{~nm}$. The integrated $J_{\mathrm{SC}}$ from the IPCE curves is $20.21 \mathrm{~mA} / \mathrm{cm}^{2}$ which is consistent with the result measured by the $J-V$ measurement systems. 
(a)

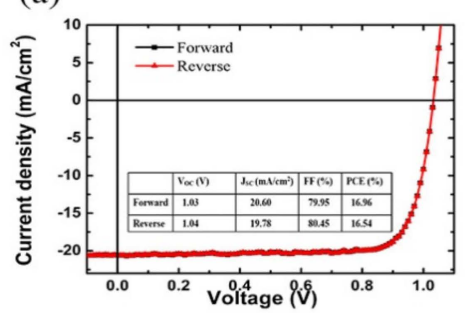

(b)

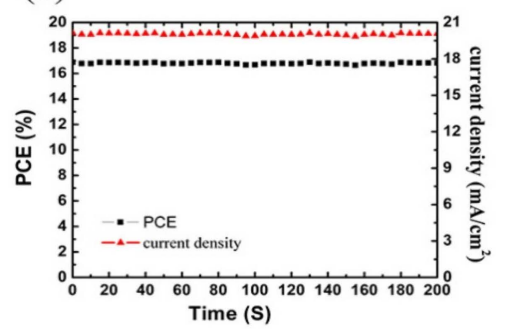

(c)

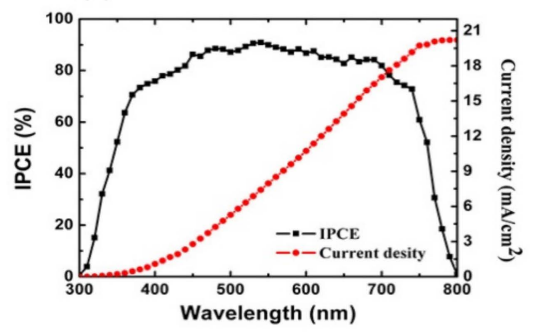

Figure 7. The optimal device performance based on the mixed anti-solvent containing 50\% toluene: (a) J-V hysteresis curves; (b) steady photocurrent and maximum PCE outputs; (c) incident photo-to current conversion efficiency (IPCE) spectrum.

Finally, we compared the stability of the unencapsulated control device based on $100 \%$ toluene and the device based on $50 \%$ toluene under ambient air condition with $22{ }^{\circ} \mathrm{C}$ and $\mathrm{RH} \leq 30 \%$ for about $200 \mathrm{~h}$. As shown in Figure 8, we found that the device adopted 50\% toluene exhibited excellent stability with PCE retaining $78 \%$ of its initial value after $200 \mathrm{~h}$. The value of $V_{\mathrm{OC}}$ remained almost unchanged, and FF and $J_{\mathrm{SC}}$ only slightly decreased to $95 \%$ and $82 \%$ of their original value. While for the control device with $100 \%$ toluene anti-solvent, the PCE value dramatically decayed to $52 \%$ of its initial value with the values of $J_{\mathrm{SC}}, \mathrm{FF}$, and $V_{\mathrm{OC}}$ all dropping dramatically during $200 \mathrm{~h}$. The morphology of perovskite films has a very important influence on their stability, especially in the ambient air [55-59]. Previous reports have shown that the stability for the dense perovskite films with larger grain size is significantly better than that of low-quality films. Additionally, the main reason for the enhancement of stability is that the larger grain size perovskite film with less grain boundary can prevent environmental damage to the film [58,59]. We can conclude that the better air stability of the PSCs adopting the mixed anti-solvent with $50 \%$ toluene is due to the improvement of the crystal quality of the perovskite film relative to the control film.

(a)

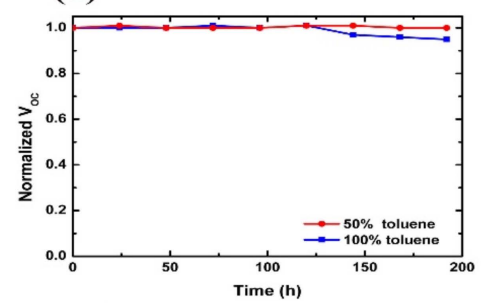

(c)

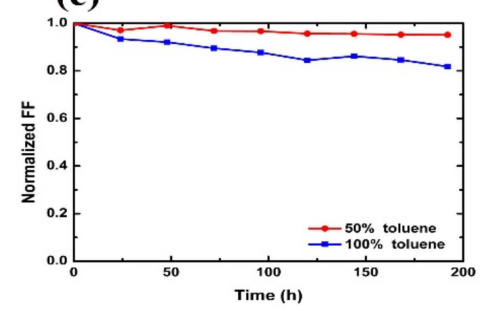

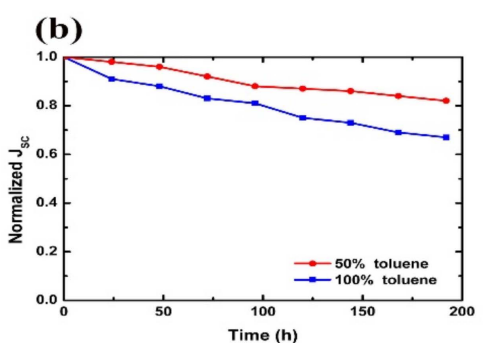

(d)

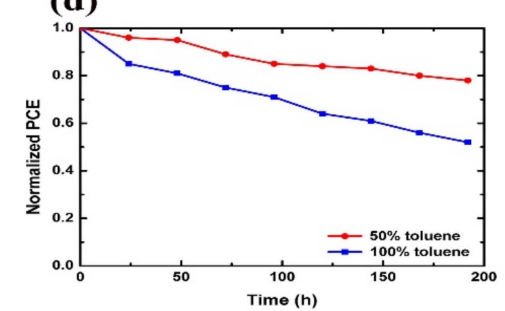

Figure 8. Stability of PSCs adopting different anti-solvents: The normalized value of (a) $V_{\mathrm{OC}}$; (b) $J_{\mathrm{SC}}$; (c) FF; and (d) PCE. 


\section{Conclusions}

In summary, we have reported a facile way to regulate the crystal quality of perovskite film by adjusting the ratio of toluene and diethyl ether in the mixed anti-solvent. The average PCE of p-i-n PSCs can be increased from $14.18 \%$ of the devices adopted the pure toluene as anti-solvent to $16.02 \%$ of the devices with $50 \%$ toluene anti-solvent. The optimal device obtains a PCE of $16.96 \%$ with a JSC of $20.60 \mathrm{~mA} / \mathrm{cm}^{2}$, a $V_{\text {OC }}$ of $1.03 \mathrm{~V}$, and a FF of $79.96 \%$ with negligible $J-V$ hysteresis effect and steady power output. Moreover, the stability of PSCs is significantly improved due to the improvement of the perovskite crystal quality adopting $50 \%$ toluene mixed anti-solvent. Therefore, our work provided an economical and effective method to enhance the performance of PSCs without increasing the complexity of the spin coating process.

Supplementary Materials: The following are available online at http://www.mdpi.com/2079-6412/9/11/766/s1. Figure S1: Optical microscope images of (a) the control perovskite film adopting pure toluene as anti-solvent and (b) the perovskite film without involving anti-solvent. The scale bar in optical microscope images is $500 \mu \mathrm{m}$. SEM topography images of (c) the control perovskite film and (d) the perovskite film without involving anti-solvent. The scale bar in SEM images is $1 \mu \mathrm{m}$. Figure S2: (a) The wavelength-dependent absorbance spectra and (b) steady-state photoluminescence (PL) spectra for control film and the film without involving anti-solvent. Figure S3: Optical microscope images of perovskite films treated with (a) $100 \%$; (b) $75 \%$; (c) $50 \%$; (d) $25 \%$; and (e) $0 \%$ toluene in the mixed anti-solvent. The scale bar in optical microscope images is images is $500 \mu \mathrm{m}$. Figure S4: SEM images and grain size distribution histograms of perovskite films treated with (a) $100 \%$; (b) $75 \%$; (c) $50 \%$; (d) $25 \%$; and (e) $0 \%$ toluene in the mixed anti-solvent. Image size was $2.5 \mu \mathrm{m} \times 2.5 \mu \mathrm{m}$. Table S1: Polarity index and boiling point of the commonly used solvent as anti-solvent. Table S2: Peak intensity of perovskite films prepared from different mixed anti-solvent obtained from XRD. Table S3: The average value of hysteresis indices (HI) of PSCs obtained with different mixed anti-solvent.

Author Contributions: C.Z. and J.Z. conceived this idea and directed the experiment; H.Y., H.W., and J.C. devised the experiment; H.Y. and H.W. performed most of the PSCs fabrication and data collection; H.Y. wrote the manuscript; C.Z. and H.W. revised the manuscript.

Funding: This research was funded by the Science and Technology Project of Baoji city, Shaanxi province, China (2018JH-03), and the National Natural Science Foundation of China under Grant 61334002 and 61106063.

Conflicts of Interest: The authors declare no conflict of interest.

\section{References}

1. Im, J.-H.; Lee, C.-R.; Lee, J.-W.; Park, S.-W.; Park, N.-G. 6.5\% efficient perovskite quantum-dot-sensitized solar cell. Nanoscale 2011, 3, 4088-4093. [CrossRef] [PubMed]

2. Lee, M.M.; Teuscher, J.; Miyasaka, T.; Murakami, T.N.; Snaith, H.J. Efficient Hybrid Solar Cells Based on Meso-Superstructured Organometal Halide Perovskites. Science 2012, 338, 643. [CrossRef] [PubMed]

3. Etgar, L.; Gao, P.; Xue, Z.; Peng, Q.; Chandiran, A.K.; Liu, B.; Nazeeruddin, M.K.; Grätzel, M. Mesoscopic $\mathrm{CH}_{3} \mathrm{NH}_{3} \mathrm{PbI}_{3} / \mathrm{TiO}_{2}$ Heterojunction Solar Cells. J. Am. Chem. Soc. 2012, 134, 17396-17399. [CrossRef] [PubMed]

4. Stranks, S.D.; Eperon, G.E.; Grancini, G.; Menelaou, C.; Alcocer, M.J.P.; Leijtens, T.; Herz, L.M.; Petrozza, A.; Snaith, H.J. Electron-Hole Diffusion Lengths Exceeding 1 Micrometer in an Organometal Trihalide Perovskite Absorber. Science 2013, 342, 341. [CrossRef]

5. Shi, D.; Adinolfi, V.; Comin, R.; Yuan, M.; Alarousu, E.; Buin, A.; Chen, Y.; Hoogland, S.; Rothenberger, A.; Katsiev, K.; et al. Low trap-state density and long carrier diffusion in organolead trihalide perovskite single crystals. Science 2015, 347, 519. [CrossRef]

6. McMeekin, D.P.; Sadoughi, G.; Rehman, W.; Eperon, G.E.; Saliba, M.; Hörantner, M.T.; Haghighirad, A.; Sakai, N.; Korte, L.; Rech, B.; et al. A mixed-cation lead mixed-halide perovskite absorber for tandem solar cells. Science 2016, 351, 151. [CrossRef]

7. Kojima, A.; Teshima, K.; Shirai, Y.; Miyasaka, T. Organometal Halide Perovskites as Visible-Light Sensitizers for Photovoltaic Cells. J. Am. Chem. Soc. 2009, 131, 6050-6051. [CrossRef]

8. Jiang, Q.; Zhao, Y.; Zhang, X.; Yang, X.; Chen, Y.; Chu, Z.; Ye, Q.; Li, X.; Yin, Z.; You, J. Surface passivation of perovskite film for efficient solar cells. Nat. Photonics 2019, 13, 460-466. [CrossRef]

9. Kim, M.; Kim, G.-H.; Lee, T.K.; Choi, I.W.; Choi, H.W.; Jo, Y.; Yoon, Y.J.; Kim, J.W.; Lee, J.; Huh, D.; et al. Methylammonium Chloride Induces Intermediate Phase Stabilization for Efficient Perovskite Solar Cells. Joule 2019. [CrossRef] 
10. Best Research-Cell Efficiency Chart. Available online: https:/www.nrel.gov/pv/assets/pdfs/best-researchcell-efficiencies.20191106.pdf (accessed on 11 November 2019).

11. Alharbi, E.A.; Alyamani, A.Y.; Kubicki, D.J.; Uhl, A.R.; Walder, B.J.; Alanazi, A.Q.; Luo, J.; Burgos-Caminal, A.; Albadri, A.; Albrithen, H.; et al. Atomic-level passivation mechanism of ammonium salts enabling highly efficient perovskite solar cells. Nat. Commun. 2019, 10, 3008. [CrossRef]

12. Yang, W.S.; Park, B.-W.; Jung, E.H.; Jeon, N.J.; Kim, Y.C.; Lee, D.U.; Shin, S.S.; Seo, J.; Kim, E.K.; Noh, J.H.; et al. Iodide management in formamidinium-lead-halide-based perovskite layers for efficient solar cells. Science 2017, 356, 1376-1379. [CrossRef] [PubMed]

13. Bakr, Z.H.; Wali, Q.; Fakharuddin, A.; Schmidt-Mende, L.; Brown, T.M.; Jose, R. Advances in hole transport materials engineering for stable and efficient perovskite solar cells. Nano Energy 2017, 34, 271-305. [CrossRef]

14. Chen, B.; Yang, M.; Priya, S.; Zhu, K. Origin of J-V Hysteresis in Perovskite Solar Cells. J. Phys. Chem. Lett. 2016, 7, 905-917. [CrossRef] [PubMed]

15. Kim, H.-S.; Jang, I.-H.; Ahn, N.; Choi, M.; Guerrero, A.; Bisquert, J.; Park, N.-G. Control of I-V Hysteresis in $\mathrm{CH}_{3} \mathrm{NH}_{3} \mathrm{PbI}_{3}$ Perovskite Solar Cell. J. Phys. Chem. Lett. 2015, 6, 4633-4639. [CrossRef] [PubMed]

16. Luo, J.; Xia, J.; Yang, H.; Chen, L.; Wan, Z.; Han, F.; Malik, H.A.; Zhu, X.; Jia, C. Toward high-efficiency, hysteresis-less, stable perovskite solar cells: Unusual doping of a hole-transporting material using a fluorine-containing hydrophobic Lewis acid. Energy Environ. Sci. 2018, 11, 2035-2045. [CrossRef]

17. Yin, X.; Chen, P.; Que, M.; Xing, Y.; Que, W.; Niu, C.; Shao, J. Highly Efficient Flexible Perovskite Solar Cells Using Solution-Derived NiOx Hole Contacts. ACS Nano 2016, 10, 3630-3636. [CrossRef] [PubMed]

18. Yang, H.; Zhang, J.; Zhang, C.; Chang, J.; Lin, Z.; Chen, D.; Xi, H.; Hao, Y. Effects of Annealing Conditions on Mixed Lead Halide Perovskite Solar Cells and Their Thermal Stability Investigation. Materials 2017, 10, 837. [CrossRef]

19. Ma, S.; Qiao, W.; Cheng, T.; Zhang, B.; Yao, J.; Alsaedi, A.; Hayat, T.; Ding, Y.; Tan, Z.a.; Dai, S. Optical-Electrical-Chemical Engineering of PEDOT:PSS by Incorporation of Hydrophobic Nafion for Efficient and Stable Perovskite Solar Cells. ACS Appl. Mater. Interfaces 2018, 10, 3902-3911. [CrossRef]

20. Sun, S.; Salim, T.; Mathews, N.; Duchamp, M.; Boothroyd, C.; Xing, G.; Sum, T.C.; Lam, Y.M. The origin of high efficiency in low-temperature solution-processable bilayer organometal halide hybrid solar cells. Energy Environ. Sci. 2014, 7, 399-407. [CrossRef]

21. Xiao, Z.; Bi, C.; Shao, Y.; Dong, Q.; Wang, Q.; Yuan, Y.; Wang, C.; Gao, Y.; Huang, J. Efficient, high yield perovskite photovoltaic devices grown by interdiffusion of solution-processed precursor stacking layers. Energy Environ. Sci. 2014, 7, 2619-2623. [CrossRef]

22. Wu, C.-G.; Chiang, C.-H.; Tseng, Z.-L.; Nazeeruddin, M.K.; Hagfeldt, A.; Grätzel, M. High efficiency stable inverted perovskite solar cells without current hysteresis. Energy Environ. Sci. 2015, 8, 2725-2733. [CrossRef]

23. Jeng, J.-Y.; Chiang, Y.-F.; Lee, M.-H.; Peng, S.-R.; Guo, T.-F.; Chen, P.; Wen, T.-C. $\mathrm{CH}_{3} \mathrm{NH}_{3} \mathrm{PbI}_{3}$ Perovskite/Fullerene Planar-Heterojunction Hybrid Solar Cells. Adv. Mater. 2013, 25, 3727-3732. [CrossRef] [PubMed]

24. Liu, X.; Cheng, Y.; Liu, C.; Zhang, T.; Zhang, N.; Zhang, S.; Chen, J.; Xu, Q.; Ouyang, J.; Gong, H. 20.7\% highly reproducible inverted planar perovskite solar cells with enhanced fill factor and eliminated hysteresis. Energy Environ. Sci. 2019, 12, 1622-1633. [CrossRef]

25. Park, N.-G. Perovskite solar cells: An emerging photovoltaic technology. Mater. Today 2015, 18, 65-72. [CrossRef]

26. Berhe, T.A.; Su, W.-N.; Chen, C.-H.; Pan, C.-J.; Cheng, J.-H.; Chen, H.-M.; Tsai, M.-C.; Chen, L.-Y.; Dubale, A.A.; Hwang, B.-J. Organometal halide perovskite solar cells: Degradation and stability. Energy Environ. Sci. 2016, 9, 323-356. [CrossRef]

27. Zuo, C.; Bolink, H.J.; Han, H.; Huang, J.; Cahen, D.; Ding, L. Advances in Perovskite Solar Cells. Adv. Sci. 2016, 3, 1500324. [CrossRef]

28. Shi, J.; Xu, X.; Li, D.; Meng, Q. Interfaces in Perovskite Solar Cells. Small 2015, 11, 2472-2486. [CrossRef]

29. Christians, J.A.; Schulz, P.; Tinkham, J.S.; Schloemer, T.H.; Harvey, S.P.; Tremolet de Villers, B.J.; Sellinger, A.; Berry, J.J.; Luther, J.M. Tailored interfaces of unencapsulated perovskite solar cells for $>1000 \mathrm{~h}$ operational stability. Nat. Energy 2018, 3, 68-74. [CrossRef]

30. Jeon, N.J.; Noh, J.H.; Yang, W.S.; Kim, Y.C.; Ryu, S.; Seo, J.; Seok, S.I. Compositional engineering of perovskite materials for high-performance solar cells. Nature 2015, 517, 476. [CrossRef] 
31. Yang, Z.; Chueh, C.-C.; Liang, P.-W.; Crump, M.; Lin, F.; Zhu, Z.; Jen, A.K.-Y. Effects of formamidinium and bromide ion substitution in methylammonium lead triiodide toward high-performance perovskite solar cells. Nano Energy 2016, 22, 328-337. [CrossRef]

32. Chen, Q.; Zhou, H.; Hong, Z.; Luo, S.; Duan, H.-S.; Wang, H.-H.; Liu, Y.; Li, G.; Yang, Y. Planar Heterojunction Perovskite Solar Cells via Vapor-Assisted Solution Process. J. Am. Chem. Soc. 2014, 136, 622-625. [CrossRef] [PubMed]

33. Li, X.; Bi, D.; Yi, C.; Décoppet, J.-D.; Luo, J.; Zakeeruddin, S.M.; Hagfeldt, A.; Grätzel, M. A vacuum flash-assisted solution process for high-efficiency large-area perovskite solar cells. Science 2016, 353, 58-62. [CrossRef] [PubMed]

34. Nie, W.; Tsai, H.; Asadpour, R.; Blancon, J.-C.; Neukirch, A.J.; Gupta, G.; Crochet, J.J.; Chhowalla, M.; Tretiak, S.; Alam, M.A.; et al. High-efficiency solution-processed perovskite solar cells with millimeter-scale grains. Science 2015, 347, 522-525. [CrossRef] [PubMed]

35. Sun, X.; Zhang, C.; Chang, J.; Yang, H.; Xi, H.; Lu, G.; Chen, D.; Lin, Z.; Lu, X.; Zhang, J.; et al. Mixed-solvent-vapor annealing of perovskite for photovoltaic device efficiency enhancement. Nano Energy 2016, 28, 417-425. [CrossRef]

36. Xiao, Z.; Dong, Q.; Bi, C.; Shao, Y.; Yuan, Y.; Huang, J. Solvent Annealing of Perovskite-Induced Crystal Growth for Photovoltaic-Device Efficiency Enhancement. Adv. Mater. 2014, 26, 6503-6509. [CrossRef]

37. Dualeh, A.; Tétreault, N.; Moehl, T.; Gao, P.; Nazeeruddin, M.K.; Grätzel, M. Effect of Annealing Temperature on Film Morphology of Organic-Inorganic Hybrid Pervoskite Solid-State Solar Cells. Adv. Funct. Mater. 2014, 24, 3250-3258. [CrossRef]

38. Jeon, N.J.; Noh, J.H.; Kim, Y.C.; Yang, W.S.; Ryu, S.; Seok, S.I. Solvent engineering for high-performance inorganic-organic hybrid perovskite solar cells. Nat. Mater. 2014, 13, 897. [CrossRef]

39. Tavakoli, M.M.; Yadav, P.; Prochowicz, D.; Sponseller, M.; Osherov, A.; Bulović, V.; Kong, J. Controllable Perovskite Crystallization via Antisolvent Technique Using Chloride Additives for Highly Efficient Planar Perovskite Solar Cells. Adv. Energy Mater. 2019, 9, 1803587. [CrossRef]

40. Prochowicz, D.; Tavakoli, M.M.; Solanki, A.; Goh, T.W.; Pandey, K.; Sum, T.C.; Saliba, M.; Yadav, P. Understanding the effect of chlorobenzene and isopropanol anti-solvent treatments on the recombination and interfacial charge accumulation in efficient planar perovskite solar cells. J. Mater. Chem. A 2018, 6, 14307-14314. [CrossRef]

41. Lee, K.-M.; Lin, C.-J.; Liou, B.-Y.; Yu, S.-M.; Hsu, C.-C.; Suryanarayanan, V.; Wu, M.-C. Selection of anti-solvent and optimization of dropping volume for the preparation of large area sub-module perovskite solar cells. Sol. Energy Mater. Sol. Cells 2017, 172, 368-375. [CrossRef]

42. Yang, H.; Zhang, J.; Zhang, C.; Chang, J.; Lin, Z.; Chen, D.; Sun, X.; Xi, H.; Han, G.; Hao, Y. Effect of polyelectrolyte interlayer on efficiency and stability of p-i-n perovskite solar cells. Sol. Energy 2016, 139, 190-198. [CrossRef]

43. Gao, Y.; Yang, L.; Wang, F.; Sui, Y.; Sun, Y.; Wei, M.; Cao, J.; Liu, H. Anti-solvent surface engineering via diethyl ether to enhance the photovoltaic conversion efficiency of perovskite solar cells to $18.76 \%$. Superlattices Microstruct. 2018, 113, 761-768. [CrossRef]

44. Wang, Y.; Wu, J.; Zhang, P.; Liu, D.; Zhang, T.; Ji, L.; Gu, X.; David Chen, Z.; Li, S. Stitching triple cation perovskite by a mixed anti-solvent process for high performance perovskite solar cells. Nano Energy 2017, 39, 616-625. [CrossRef]

45. Chen, C.; Zhang, S.; Wu, S.; Zhang, W.; Zhu, H.; Xiong, Z.; Zhang, Y.; Chen, W. Effect of BCP buffer layer on eliminating charge accumulation for high performance of inverted perovskite solar cells. RSC Adv. 2017, 7, 35819-35826. [CrossRef]

46. Yuan, D.-X.; Yuan, X.-D.; Xu, Q.-Y.; Xu, M.-F.; Shi, X.-B.; Wang, Z.-K.; Liao, L.-S. A solution-processed bathocuproine cathode interfacial layer for high-performance bromine-iodine perovskite solar cells. Phys. Chem. Chem. Phys. 2015, 17, 26653-26658. [CrossRef]

47. Chen, Q.; Zhou, H.; Song, T.-B.; Luo, S.; Hong, Z.; Duan, H.-S.; Dou, L.; Liu, Y.; Yang, Y. Controllable Self-Induced Passivation of Hybrid Lead Iodide Perovskites toward High Performance Solar Cells. Nano Lett. 2014, 14, 4158-4163. [CrossRef]

48. Docampo, P.; Hanusch, F.C.; Giesbrecht, N.; Angloher, P.; Ivanova, A.; Bein, T. Influence of the orientation of methylammonium lead iodide perovskite crystals on solar cell performance. APL Mater. 2014, 2, 081508. [CrossRef] 
49. Huang, L.; Hu, Z.; Yue, G.; Liu, J.; Cui, X.; Zhang, J.; Zhu, Y. $\mathrm{CH}_{3} \mathrm{NH}_{3} \mathrm{PbI}_{3}-\mathrm{xClx}$ films with coverage approaching $100 \%$ and with highly oriented crystal domains for reproducible and efficient planar heterojunction perovskite solar cells. Phys. Chem. Chem. Phys. 2015, 17, 22015-22022. [CrossRef]

50. Ying, C.; Shi, C.; Wu, N.; Zhang, J.; Wang, M. A two-layer structured PbI2 thin film for efficient planar perovskite solar cells. Nanoscale 2015, 7, 12092-12095. [CrossRef]

51. Ginger, D.S.; Greenham, N.C. Photoinduced electron transfer from conjugated polymers to CdSe nanocrystals. Phys. Rev. B 1999, 59, 10622-10629. [CrossRef]

52. Zhang, W.; Pathak, S.; Sakai, N.; Stergiopoulos, T.; Nayak, P.K.; Noel, N.K.; Haghighirad, A.A.; Burlakov, V.M.; deQuilettes, D.W.; Sadhanala, A.; et al. Enhanced optoelectronic quality of perovskite thin films with hypophosphorous acid for planar heterojunction solar cells. Nat. Commun. 2015, 6, 10030. [CrossRef] [PubMed]

53. Kim, H.-S.; Park, N.-G. Parameters Affecting I-V Hysteresis of $\mathrm{CH}_{3} \mathrm{NH}_{3} \mathrm{PbI}_{3}$ Perovskite Solar Cells: Effects of Perovskite Crystal Size and Mesoporous $\mathrm{TiO}_{2}$ Layer. J. Phys. Chem. Lett. 2014, 5, 2927-2934. [CrossRef] [PubMed]

54. Liu, P.; Wang, W.; Liu, S.; Yang, H.; Shao, Z. Fundamental Understanding of Photocurrent Hysteresis in Perovskite Solar Cells. Adv. Energy Mater. 2019, 9, 1803017. [CrossRef]

55. Liu, L.; Huang, S.; Lu, Y.; Liu, P.; Zhao, Y.; Shi, C.; Zhang, S.; Wu, J.; Zhong, H.; Sui, M.; et al. Grain-Boundary "Patches" by In Situ Conversion to Enhance Perovskite Solar Cells Stability. Adv. Mater. 2018, 30, 1800544. [CrossRef]

56. Seok, S.I.; Grätzel, M.; Park, N.-G. Methodologies toward Highly Efficient Perovskite Solar Cells. Small 2018, 14, 1704177. [CrossRef] [PubMed]

57. Geske, T.; Li, J.; Worden, M.; Shan, X.; Chen, M.; Bade, S.G.R.; Yu, Z. Deterministic Nucleation for Halide Perovskite Thin Films with Large and Uniform Grains. Adv. Funct. Mater. 2017, 27, 1702180. [CrossRef]

58. Chen, J.; Zuo, L.; Zhang, Y.; Lian, X.; Fu, W.; Yan, J.; Li, J.; Wu, G.; Li, C.-Z.; Chen, H. High-Performance Thickness Insensitive Perovskite Solar Cells with Enhanced Moisture Stability. Adv. Energy Mater. 2018, 8, 1800438. [CrossRef]

59. Lv, M.; Dong, X.; Fang, X.; Lin, B.; Zhang, S.; Ding, J.; Yuan, N. A promising alternative solvent of perovskite to induce rapid crystallization for high-efficiency photovoltaic devices. RSC Adv. 2015, 5, 20521-20529. [CrossRef] 